\title{
A VALIDATED REVERSED-PHASE HPLC METHOD FOR THE DETERMINATION OF VILDAGLIPTIN FROM TABLET DOSAGE FORM
}

\author{
Rahima Khatun* ${ }^{* 1}$, Md. Mirazunnabi \\ ${ }^{1}$ Department of pharmacy, University of Asia Pacific, Bangladesh \\ ${ }^{2}$ Department of pharmacy, Stamford University Bangladesh
}

\begin{abstract}
A simple, rapid, precise and cost effective method has been developed and validated for determination of Vildagliptin in pharmaceutical tablet dosage form. The chromatographic separation was carried out with Shimpack VP-ODS, $150 \times 4.6 \mathrm{~mm}$, $5 \mu \mathrm{m}$ analytical column and mobile phase containing $0.02 \mathrm{M}$ phosphate buffer $(\mathrm{pH} 4.6)$ and acetonitrile at the ratio $(80: 20 \% \mathrm{v} / \mathrm{v}) . \mathrm{pH}$ of the buffer solution was adjusted with orthophosphoric acid. The instrumental settings include flow rate $0.7 \mathrm{ml} / \mathrm{min}$, column temperature at $25^{\circ} \mathrm{C}$ and detector wavelength of $210 \mathrm{~nm}$ using a photodiode array detector. Theoretical plate for Vildagliptin was 6219 and tailing factor was 1.38.
\end{abstract}

Keywords: Vildagliptin, RP-HPLC, validation, tablet dosage form.

\section{Introduction}

Vildagliptin is an oral anti-hyperglycemic agent (antidiabetic drug). Chemically it is (S)-1[N-(3-hydroxy-1-adamantyl) glycyl] pyrrolidine-2-carbonitrile, is a potent dipeptidyl peptidase IV (dip-IV) inhibitor. DPP-IV inhibitors represent a new class of oral antihyperglycemic agents to treat patients with type 2 diabetes. DPP IV inhibitors improve fasting and postprandial glycemic control without hypoglycemia or weight gain. Vildagliptin inhibits the inactivation of GLP-1 and GIP by DPP IV, allowing GLP-1 and GIP to potentiate the secretion of insulin in the beta cells and suppress glucagon release by the alpha cells of the islets of Langerhans in the pancreas. ${ }^{[1-5]}$

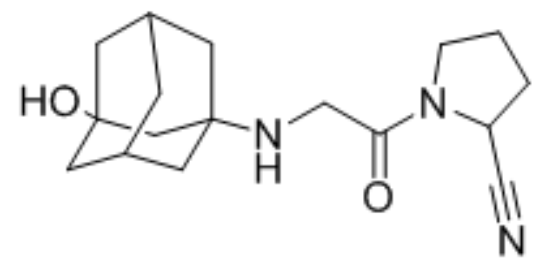

Figure 1: Structure of Vildagliptin

Literature survey reveals that few analytical methods are available for estimation of Vildagliptin. But there is no analytical method for the determination of Vildagliptin from its pharmaceutical dosage form ${ }^{[6]}$.

${ }^{*}$ Corresponding author:

Rahima Khatun

University of Asia Pacific,

Department of Pharmacy

E-mail: rahima676bph@gmail.com

Mobile: +8801749785171 
Due to lack of published chromatographic method and existing methods are time consuming and complex, the present work was aimed to develop a rapid, new, economical, precise and accurate method for the determination of Vildagliptin from its tablet dosage form.

\section{Materials and methods}

\section{Chemicals and reagents}

Working standard of Vildagliptin with a potency of $99.78 \%$ was collected from Beijing Huikang Boyuan Chemical Tech. Co. Ltd. China. Market sample of Vildagliptin (Galvus) containing $50 \mathrm{mg}$ Vildagliptin were collected from Novartis Eurofarm limited company. HPLC grade Acetonitrile was purchased from Merck, Darmstadt, Germany, Potassium dihydrogen phosphate from Scharlab, Spain and Orthophosphoric acid were purchased from Merck, Darmstadt, Germany. HPLC grade water was obtained through millipore water purification system (Model- Arium 611DI, Sartorious).

\section{HPLC instrumentation and chromatographic condition}

High performance liquid chromatographic system consisted of a Shimadzu LC-20 AT, prominence, equipped with an auto sampler (SIL-20AC HT, Shimadzu, Japan) and PDA detector (SPD- M20A, Japan) was used for the analysis. The data was recorded using LC-solution software. A shimpack VP-ODS, Shimadzu (150mm x 4.6mm, $5 \mu \mathrm{m})$ column was used for the analysis. A powersonic 505 ultrasonic bath (Hwashin technology, Seoul, Korea) was used for degassing of the mobile phase. In addition a $\mathrm{pH}$ meter (Mettler Toledo, Switzerland) and an electronic balance (Model- CP224S, Sartorious, Germany) were used in the present work.

The separation was carried out using a mobile phase consisting of $0.02 \mathrm{M}$ phosphate buffer and acetonitrile with $\mathrm{pH} 4.6$, (adjusted with orthophosphoric acid) in the ratio of $80: 20 \% \mathrm{v} / \mathrm{v}$. The mobile phase was filtered, sonicated and degassed before use. The column was maintained at a temperature of $25^{\circ} \mathrm{C}$ with column oven (CTO-20AC) and the flow rate was $0.7 \mathrm{ml} / \mathrm{min}$. Analysis was performed with injection volume of $10 \mu \mathrm{l}$ using PDA detection at $210 \mathrm{~nm}$. The run time was set for 10 minutes. The typical retention time of Vildagliptin peak is about 3.6 min which is shown in figure 2 and figure 4.

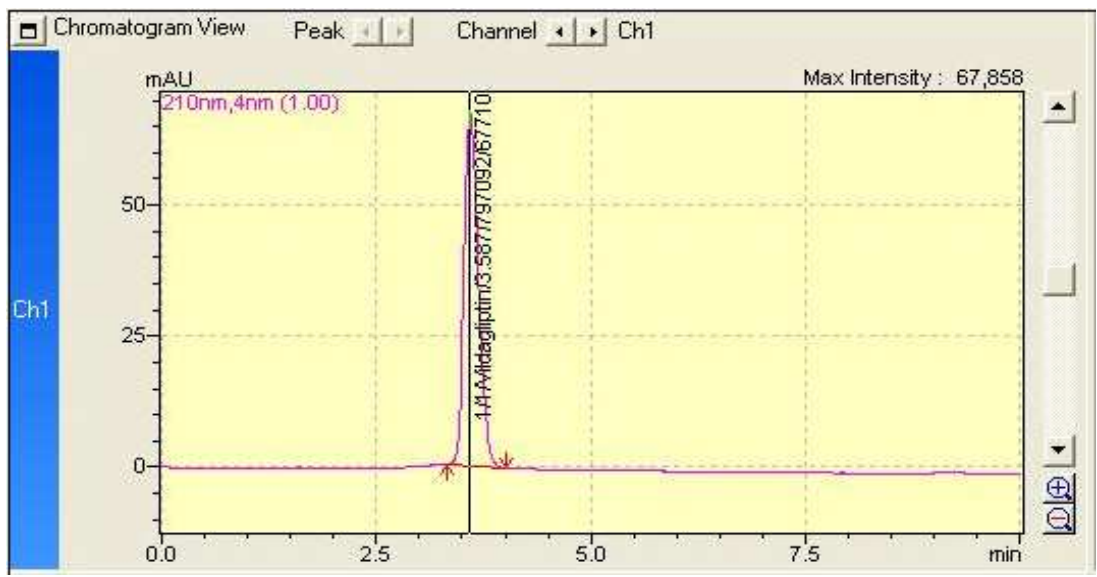

Figure 2: Chromatogram of Vildagliptin in standard solution 


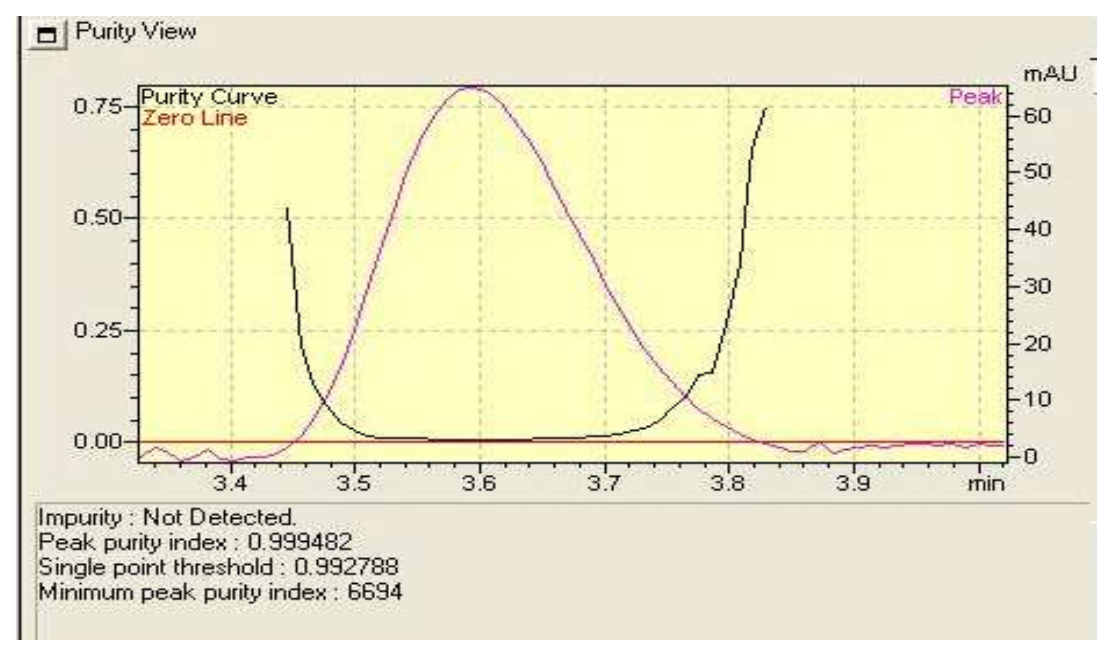

Figure 3: Purity curve of Vildagliptin in standard solution

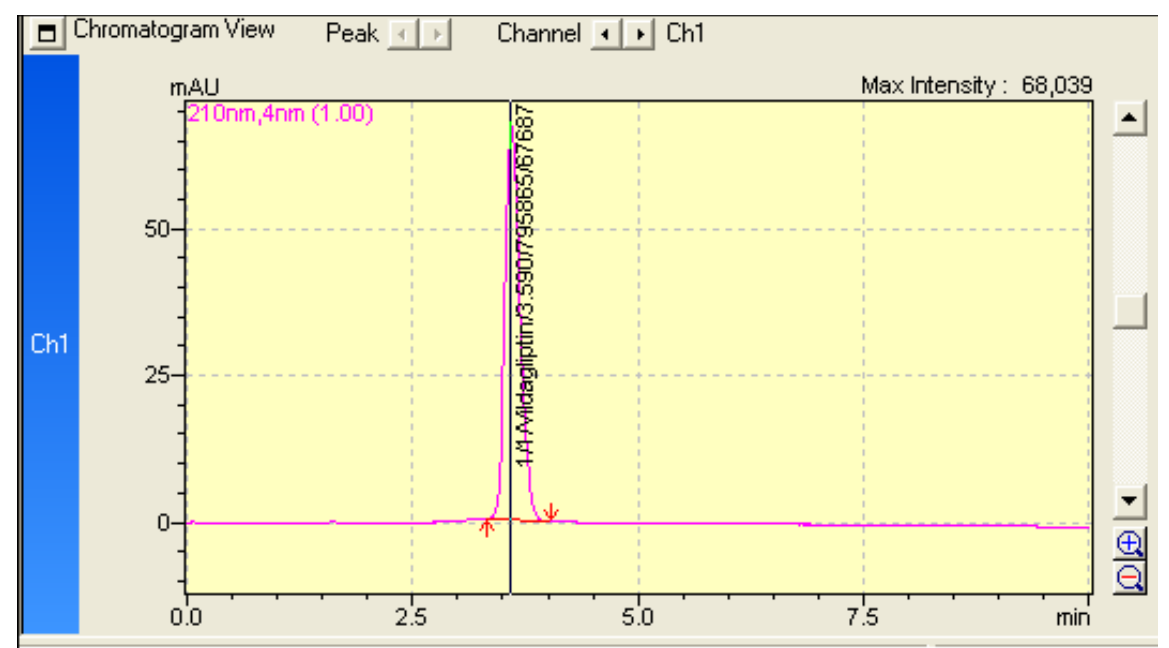

Figure 4: Chromatogram of Vildagliptin in sample solution

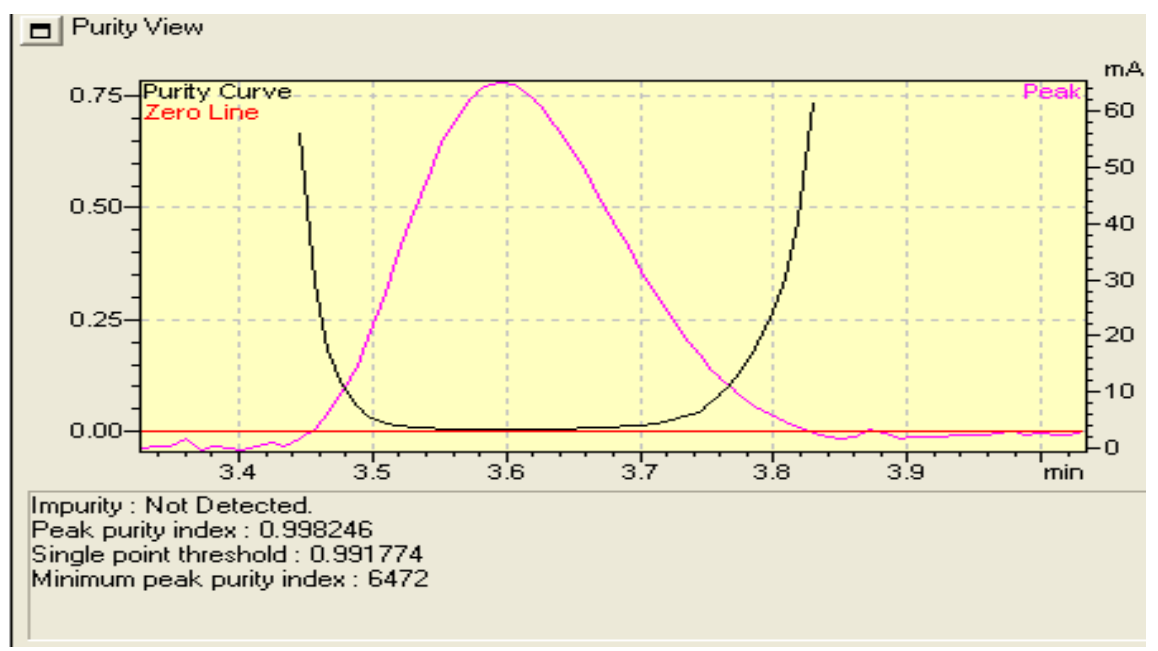

Figure 5: Purity curve of Vildagliptin in sample solution. 


\section{Preparation of standard solution}

About $50 \mathrm{mg}$ of Vildagliptin WS was accurately weighed into a $100 \mathrm{ml}$ volumetric flask and dissolved in about $60 \mathrm{ml}$ of diluting solution (20\% acetonitrile in water) and shaked by hand for 5 minutes. Then keep it for sonicate for 10 minutes. Cooled to room temperature and the volume made up with the diluting solution. $5 \mathrm{ml}$ of this solution was diluted to $50 \mathrm{ml}$ with diluting solution and mixed well. The final concentration was $50 \mu \mathrm{g} / \mathrm{ml}$ and this was used as stock solution.

\section{Preparation of sample solution}

About 20 tablets were weighed and powdered. Powders equivalent to $50 \mathrm{mg}$ of Vildagliptin were taken into a $100 \mathrm{ml}$ volumetric flask. About $3 \mathrm{ml}$ of water was added to disperse the powders, and then drugs were dissolved in $60 \mathrm{ml}$ of diluting solution and shaked at $250 \mathrm{rpm}$ for 10 minutes by shaker. The volume was made up to the mark with diluting solution and sonicated for 10 minutes. Cooled to room temperature and the resultant solution were filtered through Whatman 1 filter paper. $5 \mathrm{ml}$ of this solution was diluted to $50 \mathrm{ml}$ with diluting solution. Final solution was filtered through $0.2 \mu$-disc filter.

\section{Method validation}

The present method of analysis was conducted to obtain a new, cost effective, convenient method for HPLC determination of Vildagliptin in tablet formulation. The experimental method was validated according to the recommendations of $\mathrm{ICH}-1996$ and USP-30 for the parameters like specificity, system suitability, accuracy, linearity, precision, robustness.

\section{Specificity}

The specificity of the method was evaluated to ensure that there is no interference of excipeints, diluting solution in the chromatogram of Vildagliptin. The specificity was studied by injecting the excipients, diluting solution and standard solution of Vildagliptin.

\section{System suitability}

System suitability was performed by injecting six replicates of standards and two replicates of sample preparation at a $100 \%$ level to verify the accuracy and precision of the chromatographic system. This method was evaluated by analyzing the repeatability of retention time, tailing factor, theoretical plates of the column.

\section{Linearity}

The linearity of the chromatographic method was established by plotting a graph to concentration area of Vildagliptin standard and determining the correlation coefficient $\left(R^{2}\right)$. Linearity of Vildagliptin standard solution at a concentration level of $40 \%, 60 \%$, $80 \%, 100 \%, 120 \%, 140 \%$ were injected into the HPLC system. The detector response was found to be linear form $40 \%$ to $140 \%$ of test concentration for Vildagliptin standard. Before injection of the solutions, the column was equilibrated for at least 45 minutes with the mobile phase. Each measurement was carried out in six replicates to verify the 
repeatability of the detector response at each concentration level. Linearity curve is shown in figure 6 and data are shown in table 1.

Table 1: Linearity of Vildagliptin in Standard preparation from $40 \%$ to $140 \%$ of test concentration

\begin{tabular}{|c|c|c|c|}
\hline SI. no. & $\begin{array}{c}\text { \% test } \\
\text { concentration }\end{array}$ & Concentration $(\boldsymbol{\mu g} / \mathbf{m l})$ & Average peak area \\
\hline 1 & 40 & 20 & 319634 \\
\hline 2 & 60 & 30 & 480627 \\
\hline 3 & 80 & 40 & 639798 \\
\hline 4 & 100 & 50 & 797112 \\
\hline 5 & 120 & 60 & 953983 \\
\hline 6 & 140 & 70 & 1117742 \\
\hline & & Regression co-efficient $=$ & 1 \\
\hline
\end{tabular}

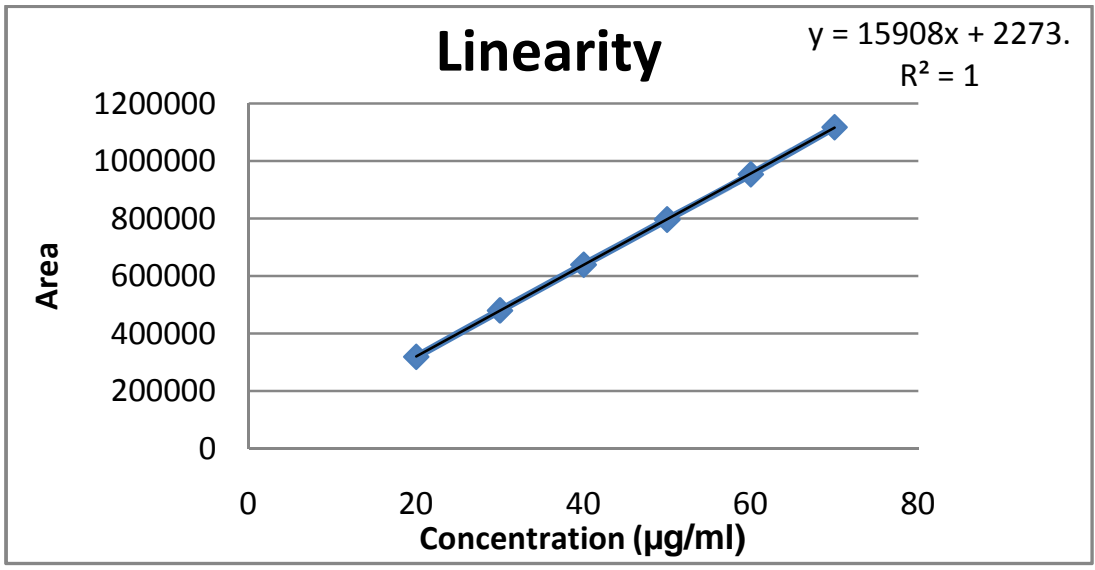

Figure 6: Calibration curve of Vildagliptin.

\section{Accuracy}

The accuracy of the method is the nearness of the result obtained to the true value. Accuracy of the method was determined by recovery experiments. The recovery was performed by adding Vildagliptin working standard to placebo (excipients mixture) in the range of test concentration $(40 \%, 60 \%, 80 \%, 100 \%, 120 \%$, and $140 \%)$ and expressed as percent (\%) recovered. Three samples were prepared for each recovery level. The recovery value for Vildagliptin ranged from 99.20 to $100.30 \%$. The average recovery of six levels was $99.73 \%$. Results are shown in table 2. 
Table 2: Results of Accuracy experiment using spiked placebo method

\begin{tabular}{|c|c|c|c|}
\hline Level (\%) & Amount of drug spiked (mg) & Found (mg) & $\begin{array}{c}\text { Recovery (\%) } \\
(\mathbf{n = 3})\end{array}$ \\
\hline 40 & 19.96 & 19.88 & 99.60 \\
\hline 60 & 29.93 & 29.69 & 99.20 \\
\hline 80 & 39.91 & 40.02 & 100.27 \\
\hline 100 & 49.89 & 50.04 & 100.30 \\
\hline 120 & 59.87 & 59.48 & 99.34 \\
\hline 140 & 69.85 & 69.62 & 99.67 \\
\hline & & Average & 99.73 \\
\hline \multicolumn{2}{r|}{} & SD & 0.463 \\
\hline & & \%SD & 0.464 \\
\hline
\end{tabular}

\section{Stability of Analytical solution}

The stability of analytical solutions was established by injecting the standard solution and sample solution at different time intervals up to 24 hours $(0,4,8,12,16,18$ and 24 hours) by keeping the auto sampler temperature at room temperature $\left(25^{\circ} \mathrm{C}\right)$. The response of standard solution and sample solution were measured and \% differences of peak area were calculated. The values are presented in the table 3.

Table 3: Stability of standard and sample solution of Vildagliptin

\begin{tabular}{|c|c|c|c|c|}
\hline \multirow{2}{*}{$\begin{array}{c}\text { Time } \\
\text { Interval }\end{array}$} & \multicolumn{2}{|c|}{ Standard } & \multicolumn{2}{c|}{ Sample } \\
\cline { 2 - 5 } & $\begin{array}{c}\text { Standard peak } \\
\text { area }\end{array}$ & $\%$ Difference & $\begin{array}{c}\text { Sample peak } \\
\text { area }\end{array}$ & \% difference \\
\hline 0 hour & 796544 & - & 795567 & - \\
\hline 4 hour & 797630 & 0.13 & 795273 & 0.04 \\
\hline 8 hour & 797082 & 0.07 & 793947 & 0.2 \\
\hline 12 hour & 796949 & 0.05 & 795120 & 0.06 \\
\hline 16 hour & 796953 & 0.05 & 795432 & 0.02 \\
\hline 18 hour & 797245 & 0.08 & 794021 & 0.2 \\
\hline 24 hours & 797895 & 0.2 & 795089 & 0.06 \\
\hline
\end{tabular}

\section{Precision}

The precision of an analytical method is the degree of agreement among individual test results where the method is applied repeatedly to multiple samplings. Precision of the assay was assessed with respect to repeatability, reproducibility and intermediate precision by estimating the assay for six different sample preparations of same batch. 
Results of analysis for repeatability, intermediate precision, and reproducibility are given in the table 4.

Table 4: Statistical analysis for repeatability, intermediate precision and reproducibility of Vildagliptin $\mathbf{5 0} \mathbf{~ m g}$ Tablet

\begin{tabular}{|c|c|c|c|}
\hline \multirow{2}{*}{ Sample ID } & \multicolumn{3}{|c|}{ Assay ( \% labeled amount) } \\
\cline { 2 - 4 } & $\begin{array}{c}\text { Repeatability } \\
\text { (Analyst 1) }\end{array}$ & $\begin{array}{c}\text { Intermediate } \\
\text { precision ( Analyst } \\
\text { 2) }\end{array}$ & $\begin{array}{c}\text { Reproducibility } \\
\text { ( Analyst 3) }\end{array}$ \\
\hline Sample-1 & 99.83 & 100.04 & 98.32 \\
\hline Sample-2 & 99.67 & 99.59 & 99.85 \\
\hline Sample-3 & 100.13 & 99.41 & 99.02 \\
\hline Sample-4 & 98.99 & 99.20 & 100.53 \\
\hline Sample-5 & 99.29 & 98.97 & 99.08 \\
\hline Sample-6 & 99.31 & 99.17 & 99.26 \\
\hline Average & 99.54 & 99.40 & 99.34 \\
\hline SD & 0.416 & 0.380 & 0.760 \\
\hline \% RSD & 0.418 & 0.383 & 0.766 \\
\hline
\end{tabular}

\section{Robustness}

The robustness is the ability of method to remain unaffected by small changes in parameters. The robustness of the method were determined by purposely altering experimental conditions and \% assay of Vildagliptin, peak tailing, theoretical plates, \% RSD were calculated. To study the effect of flow rate, it was changed to 0.2 units from $0.7 \mathrm{ml} / \mathrm{min}$ to $0.5 \mathrm{ml} / \mathrm{min}$ and $0.9 \mathrm{ml} / \mathrm{min}$. The effect of column temperature was studied at $23^{\circ} \mathrm{C}$ and $27^{\circ} \mathrm{C}$ instead of $25^{\circ} \mathrm{C}$. The effect of $\mathrm{pH}$ change was studied by changing the buffer $\mathrm{pH}$ from 4.6 to 4.4 and 4.8 . Results are shown in the table 5 .

Table 5: Results of robustness study

\begin{tabular}{|c|l|c|c|}
\hline $\begin{array}{c}\text { SI. } \\
\text { No. }\end{array}$ & \multicolumn{1}{|c|}{ Parameter } & \multicolumn{1}{|c|}{ Variation } & Assay $\%$ (n=3) \\
\hline 1. & Flow rate $( \pm 20 \%$ of the set flow $)$ & $\begin{array}{l}\text { a) at } 0.5 \mathrm{ml} / \mathrm{min} \\
\text { b) at } 0.9 \mathrm{ml} / \mathrm{min}\end{array}$ & $\begin{array}{l}\text { a) } 98.88 \\
\text { b) } 99.23\end{array}$ \\
\hline $\mathbf{2 .}$ & $\begin{array}{l}\text { Mobile phase } \mathrm{pH}( \pm 0.2 \text { of set } \\
\mathrm{pH})\end{array}$ & $\begin{array}{l}\text { a) at } \mathrm{pH} 4.4 \\
\text { b) at } \mathrm{pH} 4.8\end{array}$ & $\begin{array}{l}\text { a) } 99.06 \\
\text { b) } 99.17\end{array}$ \\
\hline 3. & $\begin{array}{l}\text { Column oven temperature }\left( \pm 2^{\circ} \mathrm{C}\right. \\
\text { of set temperature })\end{array}$ & $\begin{array}{l}\text { a) at } 23^{\circ} \mathrm{C} \\
\text { b) at } 27^{\circ} \mathrm{C}\end{array}$ & b) 99.56 \\
\hline
\end{tabular}




\section{Results and discussion}

The developed method was specific because there was no interference of excipients, diluting solution and impurity in the chromatogram of Vildagliptin (purity curve shown in figure 3 and 5). The method showed linearity of detector response and produces a linear calibration curve over the range of $20-70 \mu \mathrm{g} / \mathrm{ml}$ (Figure 6). Results of accuracy were proven by the table 2 and \% RSD is 0.464 , which is within the acceptable limit. The \% difference of peak area of Standard solution and Sample solution that were injected at periodic intervals were found to be within the specified limit (Table3). Results for robustness evaluation for Vildagliptin (Table 5) were also satisfactory. So, this method is applicable for determination of Vildagliptin from its tablet dosage form.

\section{Conclusion}

The proposed RP-HPLC has been validated as per the recommendation of $\mathrm{ICH}$ guidelines. The method is accurate, precise, simple, less time consuming, cost effective and convenient for use. All the validation parameters of the analysis method showed satisfactory data with acceptable correlation co-efficient and lower \% RSD. So the developed method can be used conveniently for analysis of quality control, stability and further studies.

\section{Acknowledgement}

The authors thank S M Ashraful Islam, Associate professor and co-ordinator, Department of Pharmacy, University of Asia Pacific, Bangladesh for providing required facilities to carry out the project work.

\section{References:}

1. A. B. Pharne, B. Santhakumari, A. S. Ghemud, H. K. Jain, M. J. Kulkarni. Bioanalytical method development and validation of vildagliptin a novel dipeptidyl peptidase iv inhibitor by rp-hplc method. International Journal of Pharmacy and Pharmaceutical Sciences. Vol 4, Issue 3, 2012.

2. Lauster CD, McKaveney TP, Muench SV. Levalbuterol: A novel oral therapy for type 2 diabetes mellitus. Am J Health Syst Pharm. 2007,64, 1265-1273.

3. Handan He, Phi Tran, Hequn Yin, Harold Smith, Yannick Batard, Lai Wang, Heidi Einolf, Helen Gu, James B. Mangold, Volker Fischer and Dan Howard. Absorption, Metabolism, and Excretion of [14C] Vildagliptin, a Novel Dipeptidyl Peptidase 4 Inhibitor, in Humans, Drug Metabolism and Disposition, 2009, 37, 536-544.

4. Razia Sultana, Sitesh C. Bachar and Fatema Rahman. Development and validation of stability indicating assay method of vildagliptin in bulk and tablet dosage form by RP-HPLC. International journal of pharmacy \& life sciences.Vol 4, issue 4, p 2530-2534: April 2013 
5. Subhakar Nandipati, V. Krishna Reddy, T. Ravindranadh Reddy. Development and Validation of RP-HPLC method for Simultaneous Determination of Vildagliptin and Metformin in Bulk and Formulation Dosage. International Research Journal of Pharmaceutical and Applied Sciences. Int. Res J Pharm. App Sci., 2012; 2(3):4450.

6. Aparajita malakar, Bishwajit Bokshi, Dilruba Nasrin. Development and validation of rp-hplc method for estimation of Vildagliptin from tablet dosage form. International Journal of Pharmaceutical and Life Sciences. Volume 1, Issue 1, Serial 2: August 2012. 